\title{
Translating to Communicate with Linguistic Minorities: State obligations under international law
}

\author{
Gabriel González Núñez ${ }^{1}$ \\ KU Leuven ${ }^{2}$
}

\begin{abstract}
In the on-going debate about language rights, the role of translation remains somewhat of a blind spot. And yet, because there are very few truly monolingual societies in the world, any language policy implies a translation policy. Translation policies will vary from place to place, and they are often the result of ad hoc choices by policy makers at the local level. Even so, by looking at international law, we can find a sort of lowest common denominator for what is to be expected of translation policies. Sources of international law that can have an effect in shaping domestic policies include treaties/conventions and the judicial decisions of international tribunals. In Europe in particular, a number of regional treaties from the Council of Europe weigh on translation as an instrument to guarantee the rights of minority speakers. The European Union - with its own treaties, regulations, and directives - also helps set minimum standards for domestic translation policies. We will see that in Europe translation is usually cast as a means to secure other rights. Unfortunately, international law seems to set a rather low bar for this, with the most explicit protections afforded in the judicial realm but with relatively little elsewhere.
\end{abstract}

\section{Introduction}

The issue of language rights has come to the forefront in the last decades, as evidenced by the literature on the subject and the political changes that have taken place granting greater rights to minorities (many of which speak languages other than the majority language). As countries adjust their language policies, many social, political, economic, and legal forces have come into play. Of particular interest for the scope of this study are the legal forces that have helped language policy evolve, especially when it comes to translation for linguistic minorities. Legal developments within each state are affected by many factors, including what they see their neighbours doing. Modern European states, for example, often compare their social policies, including language and translation policies, against those of other states or seek to adopt what they see as European social policies. ${ }^{3}$ Those common policies help drive international law,

\footnotetext{
${ }^{1}$ The author would like to thank Andrew Chesterman, Fernand de Varennes, Reine Meylaerts, Anthony Pym, and the journal's peer reviewers for their insights which contributed to the development of this paper.

${ }^{2}$ This research was carried out within a project named TIME (Translation Research Training: An Integrated and Intersectoral Model for Europe - FP7-PEOPLE-2010-ITN) made possible through the support of the European Commission.

${ }^{3}$ N. Lendvai and P. Stubbs, 'Policies as Translation: Situating Transnational Social Policies', in S. Hodgson and Z. Irving (eds.), Policy Reconsidered: Meanings, Politics, and Practices (The Policy Press, Bristol, 2007), p. 174.
} 
which in turn fosters developments in domestic law. Indeed, international law permeates domestic law more and more. Consequently, when trying to understand domestic legal developments, some aspects of international law may need to be taken into account. This is so because international law offers a sort of legal common denominator for states, not just in their interactions with each other but also in their domestic policies. Therefore, this study sets out to answer the following question: Under existing international law, what translation must take place in domestic policies? Because one of the aims of this study is to understand if translation policies are intended to integrate linguistic minorities, we will be on the lookout for any links between translation obligations under international law and issues of integration.

The question is relevant because it is linked to language rights, a topic that has not gone unnoticed in international law. In this study, language rights are defined as those rights that allow members of a language community to be free from state interference in the private and public use of their own language and to be protected by the state in said use when it comes to the full enjoyment of other rights provided by law. Under this definition, individuals may have the right to use their language in private and in public (and to be attended in that language by the state authorities), the right to have their children be educated in that language, and other judicial rights which are guaranteed by law. The right to translation would be derived from those language rights. To explore how translation can be construed as a language right, we lean on Rubio-Marín distinction between instrumental and noninstrumental language rights. ${ }^{4}$

Non-instrumental language rights are those granted because of the state's underlying ideology that a certain group is entitled to the protection and even promotion of its language. ${ }^{5}$ Thus, they reflect the state's commitment "to help a certain collectivity achieve the goal of protecting its language". 6 Translation may play a role in helping grant non-instrumental language rights, particularly when a lot of material that is produced in the majority language for the entire state must also be produced in the language of the collectivity in question. On the other hand, instrumental language rights are those granted with the "aim at ensuring that language is not an obstacle to the effective enjoyment of rights with a linguistic dimension, to the meaningful participation in public institutions and democratic process, and to the enjoyment of social and economic opportunities that require linguistic skill". ${ }^{7}$ Of course,

\footnotetext{
${ }^{4}$ R. Rubio-Marín 'Language Rights: Exploring the Competing Rationales', in W. Kymlicka and A. Patten (eds.), Language Rights and Political Theory (Oxford University Press, Oxford, 2003), pp. 56-58.

${ }^{5}$ Ibid., p. 57.

${ }^{6}$ Ibid.

${ }^{7}$ Ibid., p. 56.
} 
when the state grants instrumental language rights, it is to individuals who lack the necessary proficiency in the language of the state to effectively enjoy another right. Instrumental language rights can be granted through translation as a sort of accommodation when language becomes an obstacle for the enjoyment of rights.

This distinction is a helpful analytical tool, because it can help us see whether translation is intended to help individuals have greater access to the state and its services (instrumental) or whether it is meant to promote one or more languages (non-instrumental). To be fair, there may be overlapping between both types of rights. For example, a government may decide to adopt a number of measures to promote a local language even though the population speaks the majority language as well as the local language. This may result in noninstrumental language rights. However, if there are individuals who speak the local language only and not the majority language, translation for them would be aimed at securing instrumental language rights. For purposes of this study, we will consider what the main objective is behind the granting language rights. If said rights are mostly intended to promote a language, we will consider them non-instrumental. If they are mostly intended to remove obstacles from the enjoyment of other rights, we will consider them instrumental. As we do this, we will see that for the most part, the international community sees translation as a tool for implementing instrumental language rights.

\section{Translation as mandated by general international law}

\subsection{Two general principles: freedom of expression and equality/non-discrimination}

Language rights that are pertinent to translation, in order to be meaningful to individuals, must be realized through state policy. As explained above, that policy may be constrained by obligations under international law. What we understand to be language rights under international law, as found in the relevant instruments, often derive from freedom of expression as well as equality and non-discrimination. These two principles are frequently present in the texts of international legal instruments.

Regarding translation, the argument could be made that freedom of expression on the one hand and equality and non-discrimination on the other would surely imply that a minority language speaker can use the language of his or her choosing (and then the government would have to translate) or that in order for the government to communicate with a minority language speaker without discriminating against him or her, the government would have to 
use that speaker's language (often through translation). Except that is not really what freedom of expression and equality/non-discrimination imply in international law.

As De Varennes points out, freedom of expression guarantees the right to choice of language in private matters only (i.e., in the non-governmental realm), and even that can be restricted if the restriction is predicated upon a rational need and proportional to the aim that needs to be achieved (such as public order, health, or morals). ${ }^{8}$ Therefore, under international law, freedom of expression does not guarantee the right to have the authorities translate materials into one's own language. ${ }^{9}$ In essence, this freedom does not impose a restriction upon the government's choice of language for interacting with individuals. ${ }^{10}$

When international law talks about equality and non-discrimination, it refers to being equal before the law. Legal equality does not mean that everyone has to be treated exactly the same. There may indeed be a rational basis for a proportional, differential treatment. Under legal equality, however, differential treatment cannot be based upon certain grounds, which are restricted by law. It is common-place for human rights instruments, both general and regional, to cite language as such an impermissible grounds for discrimination. Thus, "the exclusive use of a single language constitutes differential treatment which may in some cases be discriminatory". ${ }^{11}$ As indicated above, a government can discriminate on the basis of language if there is a rational basis for such discrimination and that discrimination is proportionate. ${ }^{12}$ De Varennes identifies the following grounds that make it permissible for a government to have language preferences: national unity, number of speakers and their concentration, whether the language is spoken by citizens or non-citizens, practical considerations related to limited resources, compensatory means to eliminate the effects of historically oppressive practices, socio-cultural and religious considerations, legitimacy of the goal sought after, and proportionality of the goal to the means employed. ${ }^{13}$ What this means is

\footnotetext{
${ }^{8}$ F. De Varennes, Language, Minorities and Human Rights (1996), pp. 39-42.

${ }^{9}$ This is evident when considering that the European Commission of Human Rights found no violation of freedom of expression when individuals under different circumstances were asked to use the State's language in the following cases: Inhabitants of Leeuw - St. Pierre v. Belgium, X v. Ireland, and Fryske Nasjonale Partij v. Netherlands. I. Ulasiuk, 'Language Rights in Relations with Public Administration', 18 International Journal on Minority and Group Rights (2011) p. 97.

${ }^{10}$ This goes to show how weak a protection freedom of expression is when it comes to language rights. For example, the UN Human Rights Committee has indicated that a government may require the use of an additional language besides the individual's language of choice since the individual is still free to express the ideas in his or her own language alongside another language. De Varennes, supra note 8, p. 50. Of course, if an individual is forced to use a language other than his or her own to communicate with the government, the usefulness of the non-governmental language is curtailed. This could in the long run have a chilling effect that could lead individuals to gradually stop using the less-useful language, which arguably curtails their freedom of expression!

${ }^{11}$ De Varennes, supra note 8, p. 75.

${ }^{12}$ De Varennes, supra note 8, p. 76.

${ }^{13}$ De Varennes, supra note 8, pp. 88-100.
} 
that based on equality and non-discrimination, a government has a very wide range of discretion (or margin of appreciation) when selecting its language preferences, which is to say, when implementing its language policy.

As the two preceding paragraphs show, the many calls for freedom of expression and equality/non-discrimination that are found in international instruments do not per se mean that governments must translate for linguistic minorities. Therefore, we need to look at provisions that more specifically call for translation. Narrow provisions that call upon governments to translate for linguistic minorities are found in the Geneva Conventions, ILO Convention No. 169, the International Covenant on Civil and Political Rights, and the International Convention on the Protection of the Rights of all Migrant Workers and Members of their Families. We will now look at each one in turn.

\subsection{Geneva Conventions}

The Geneva Conventions are among the first instruments in international human rights law to address the issue of translation for speakers of a language other than the government's, albeit in a very narrow context. The drafters of these documents were concerned with ameliorating the horrors of war, not with integrating linguistic minorities, so the narrowness of the context should not be surprising. Even though the Geneva Conventions apply to times of war and occupation, they are interesting because they are high-profile treaties that include some concern for translation. Further, some of the translation provisions found in these conventions were later echoed in other, unrelated treaties and therefore expanded to situations of nonbelligerence.

The Geneva Convention Relative to the Treatment of Prisoners of War (Third ${ }^{14}$ Geneva Convention) very much concerns fairness in the treatment of prisoners of war. It is rather conservative, however, when weighing in as to whether a fair treatment means providing translations when needed. Translation is potentially called for in Articles 17, 41, 96, 105 , and 107.

Article 17 reads simply: "The questioning of prisoners of war shall be carried out in a language which they understand." This article, which deals with the beginning of the

\footnotetext{
${ }^{14}$ The Convention for the Amelioration of the Condition of the Wounded and Sick in Armed Forces in the Field, or First Geneva Convention, does not directly address translation issues. The Convention for the Amelioration of the Condition of Wounded, Sick and Shipwrecked Members of Armed Forces at Sea, or Second Geneva Convention, implies translation in a very specific circumstance. Article 31 reads in part: “... As far as possible, the Parties to the conflict shall enter in the log of the hospital ship in a language he can understand, the orders they have given the captain of the vessel." This narrow obligation is hedged ("As far as possible") so as to make it easily dismissed.
} 
prisoner's captivity, implies the use of an interpreter if the prisoner does not understand the language of his or her captors. The Commentary to the Convention signals that the questioning need not take place in the prisoner's first language, only in a language that he or she will understand. ${ }^{15}$ Thus, there is no real concern for whether the prisoner has a right to use his or her own language, but merely a practical consideration of being able to communicate with the prisoner.

Article 41 in turn deals with measures during the internment of the prisoners. It calls for the text of the Convention to be posted or distributed in the "the prisoners" own language". This implies translation, but into what languages? The Commentary defines "the prisoner's own language" as "the official language of the prisoners' country of origin". ${ }^{16}$ Where more than one language is official in a country of origin, the Convention should be posted "in the language actually used by the prisoners concerned" if that language also happens to be an official language in the prisoners' country. ${ }^{17}$ The assumption seems to be that most, if not all, prisoners will have enough of a grasp of their state's official language(s) to read an international treaty in that language. No thought seems to be given to prisoners who do not meet that expectation. One must conclude that they either do not exist or do not matter.

Article 41 further calls for "Regulations, orders, notices and publications of every kind relating to the conduct of prisoners of war" as well as "Every order and command" to be issued in a language the prisoners understand. ${ }^{18}$ If the prisoners do not speak the language of the captors, this can imply either an on-going language teaching effort or a sustained, regular translation effort. For at least one delegate present at the drafting conference, the implication was translation. During a committee meeting, a Turkish representative objected to having to provide translations into many languages, particularly if the languages were lesser used languages. $^{19}$

The next three articles we will focus on deal with disciplinary and penal procedures. Article 96 deals specifically with disciplinary actions against prisoners of war. It calls for a prisoner of war accused of indiscipline to be informed of the accusation and to be allowed to defend him or herself. In this process, the prisoner is "to have recourse, if necessary, to the

\footnotetext{
${ }^{15}$ J. de Preux et al., Commentary on the Geneva Conventions of 12 August 1949. Volume III. (International Committee of the Red Cross, Geneva, 1960), p. 157.

${ }^{16}$ Ibid., p. 244.

${ }^{17}$ Ibid.

${ }^{18}$ A Dutch delegate to the diplomatic conference that drafted the convention proposed an amendment to have the translations into the prisoner's "mother tongue". Federal Political Department of Switzerland, Final Record of the Diplomatic Conference of Geneva of 1949, Vol. II, Sec. A. (Berne, 1950) p. 265. The proposal did not prosper.

${ }^{19}$ Ibid. 
services of a qualified interpreter". Article 105, which deals with the prisoner's right of defence in a trial setting, indicates that the accused "if he deems necessary" may have the assistance "of a competent interpreter" 20 during the trail. The "Particulars of the charge" and the "documents which are generally communicated to the accused" must be communicated to the prisoner "in a language which he understands." This implies translation in some situations, even though not necessarily into the prisoner's native language. Finally, Article 107 concerns itself with the communicating of the sentence. It states that if the sentence was not pronounced in the accused's presence, it must be sent to him "in a language he understands". These three articles together reflect a concern with a general principle of law, that of a fair trial for the accused. If the prisoner is going to have further limitations imposed upon his or her liberty, then the prisoner needs to know what the accusation is, to have the ability to defend him or herself, and to understand the outcome of the proceedings.

The Third Geneva Convention indicates that nations should have a policy of procedural fairness toward captured enemies, particularly in disciplinary and trial settings, and in certain circumstances, that policy can only be achieved through the use of translation. A similar linguistic policy should be adopted toward civilians under military occupation, according to articles $65,71,72$, and 99 of the Geneva Convention relative to the Protection of Civilian Persons in Time of War (Fourth Geneva Convention).

Article 65 mandates that the "penal provisions" of the occupying power must be "published and brought to the knowledge of the inhabitants in their own language". Here again, the Commentary indicates that "their own language" is really the official language of the occupied country, not necessarily the language spoken by the local populations. ${ }^{21}$ If the country has several official languages, the publication should follow whatever was customary in that place regarding the publication of laws before the occupation. ${ }^{22}$ The idea is that people should not be judged according to unknown laws. Limiting translation activities to official languages may be more than likely due to practical concerns. Indeed, concern was expressed during the drafting conference that too much translation would be burdensome. Even so, there seems to be also an assumption in this article that everyone that lives in a specific place

\footnotetext{
${ }^{20}$ What exactly is the difference between a "competent" (Art. 105) and a "qualified" (Art. 96) interpreter is hard to tell. The Commentary points out that qualified is a stronger adjective than competent, yet a competent interpreter will do for higher-stake proceedings (trials) but for lower-stake proceedings (disciplinary actions) the interpreter must merely be "qualified". J. de Preux, supra note 13, pp. 460-461, 487. Perhaps there is no real distinction between the two in this treaty.

${ }^{21}$ J. de Preux, supra note 15, p. 338.

${ }^{22}$ Ibid. 
speaks the official language of that place. ${ }^{23}$ This may not always be the case, particularly in some rural communities and among immigrants.

Articles 71 and 72 deal with judicial procedures, and they both mirror Article 105 of the Third Geneva Convention in regards to translation. Article 71 calls for prosecuted individuals to be made aware of the charges "in a language which they understand". Article 72 indicates that accused individuals will be assisted by an interpreter during preliminary investigations and the actual hearings, unless such individuals "freely waive such assistance". They may also object to a particular interpreter and ask that he or she be replaced.

Article 99 deals with the treatment of internees and it mirrors Article 41 of the Third Geneva Convention. Among other provisions, Article 99 calls for "[r]egulations, orders, notices and publications [...] to be communicated to the internees and posted inside the places of internment, in a language which they understand." Similarly, orders to individual internees must be issued "in a language which they understand". When there are language differences, this calls for bilingual staff or translation, or a mixture of both. This article stresses that "internees" must have access to a copy of the Convention in a language they can understand. The Commentary indicates that in this context, internees usually will understand the official language of the country where they are detained, but if not, translations into "foreign" languages must be provided as needed. ${ }^{24}$

Because they deal with conduct in times of war, the Geneva Conventions are narrow in their linguistic applications. Even so, they reflect principles of fairness, particularly when it comes to judicial and penal procedures. The drafters of the Geneva Conventions understood that if someone stood before a tribunal who did not speak the language of the tribunal, proceeding without some form of translation would be unfair. Thus, linguistic protections are called for. These are not triggered by the defendant's nationality or linguistic preference, but rather by his or her inability to understand the proceedings (or laws, rules and orders). The linguistic protections found in the Geneva Conventions, which at times can only be achieved through translation, are so obvious that they are found under international law in areas far removed from the horrors of war.

\subsection{International Covenant on Civil and Political Rights}

\footnotetext{
${ }^{23}$ J. de Preux, supra note 15, p. 430.

${ }^{24}$ J. de Preux, supra note 15, p. 430-431. 
The International Covenant on Civil and Political Rights (ICCPR) is one of three documents that are considered to be the International Bill of Rights. ${ }^{25}$ The obligations set forth in the ICCPR are monitored by the Human Rights Committee (HRC), to which all parties are required to self-report. States are permitted to file complaints before the HRC, and individuals from states parties to the first Optional Protocol can also file complaints. Thus, the HRC serves as a forum of redress, even though it is not strictly speaking a tribunal. Even so, the HRC's General Comments to the ICCPR are authoritative interpretations (Scheinin 2008: 24).

The ICCPR reflects the same concern for fairness in judicial proceedings as the Geneva Conventions, particularly as seen in Articles 105 and 106 of the Third Geneva Convention. The ICCPR's Article 14 refers to criminal proceedings. Among the "minimum guarantees" outlined in 14.3, we find that everyone is entitled "(a) To be informed promptly and in detail in a language which he understands of the nature and cause of the charge against him". It should be noted that, much like with the Geneva Conventions, "a language which he understands" is not necessarily the accused person's native language. This was settled in Guesdon v. France, where the HRC signalled that the requirement for the assistance of an interpreter in court proceedings applies only when the accused is not "capable of expressing himself adequately in the official language" and should not be construed as a right to choose the accused's native language if he or she can speak the "official language". ${ }^{26}$ Regarding interpreting, Article 14.3 further indicates that everyone is entitled "(f) To have the free assistance of an interpreter if he cannot understand or speak the language used in court." The HCR has clarified that this right to a free interpreter applies to nationals and non-nationals and is not contingent upon the trial's outcome. ${ }^{27}$ This right, however, does not extend to noncriminal court proceedings. ${ }^{28}$

At most, that is all the ICCPR stands for: the right to translation in criminal proceedings. As will be seen below, subsequent instruments will expand this, but not very broadly. Basically, very few international instruments call for translation beyond the context

\footnotetext{
${ }^{25}$ The International Bill of Rights is comprised on the Universal Declaration of Human Rights, the ICCPR, and the International Covenant on Economic, Social, and Cultural Rights. Of these three, translation appears as a right only in the ICCPR.

${ }^{26}$ In this case, Mr. Guesdon wanted to testify in Berton, through an interpreter. He spoke French, but he considered Breton to be his native and stronger language. The Committee's finding was made under Article 14. Mr. Guedson also raised the issue the of Article 27's guarantees to persons of “ethnic, religious or linguistic minorities" to the "use their own language." The Committee, however, felt the facts did not raise Article 27 issues.

${ }^{27}$ United Nations, International Human Rights Instruments. Vol I. Compilation of General Comments and General Recommendations Adopted by Human Rights Treaty Bodies (2008), p. 187.

${ }^{28}$ Ibid., 209.
} 
of criminal proceedings. ${ }^{29}$ In fact, several of the instruments that followed the ICCPR limited themselves to reiterating this narrow right to translation. ${ }^{30}$

\subsection{ILO Convention (No. 169) concerning Indigenous and Tribal Peoples in}

\section{Independent Countries}

The International Labour Organization Convention (No. 169) concerning Indigenous and Tribal Peoples in Independent Countries (Convention 169) is the major international instrument dealing with the rights of indigenous peoples. ${ }^{31}$ Compared to the ICCPR, the rights to translation found in Convention 169 are both narrower in applicability and broader in scope. They are narrower in terms of who they apply to. Convention 169 applies to "indigenous peoples", a term that is vaguely defined in Article 1, thus leaving the task of identifying specific groups to each state party to the Convention. Article 1 clearly indicates that the protections in the Convention apply only to individuals who belong to an indigenous group. To those who do belong to such groups, the right to translation is broader than under the ICCPR.

Articles 12 deals with proceedings where the protection of the peoples' rights may be at issue: "Measures shall be taken to ensure that members of these peoples can understand and be understood in legal proceedings, where necessary through the provision of interpretation or by other effective means." At first brush this may seem to echo the rights in the ICCPR, but this is much broader. Article 12 effectively refers to all legal proceedings, not just criminal proceedings. Under this Article, the availability of interpreting in legal proceedings is not merely a matter of fairness. It is specifically a tool to allow indigenous peoples to protect their rights by being able to effectively "take legal proceedings". The assumption behind this right to translation is that indigenous peoples are often unable to communicate in the language of

\footnotetext{
${ }^{29}$ Alanen. 'Language Access is an Empowerment Right: Deprivation of Plenary Language Access Engenders an Array of Grave Rights Violations'. 1:3 International Legal Studies Program Law Journal (2009), p. 102.

${ }^{30}$ See e.g., the 1989 Convention on the Rights of Child. With the exception of the notion of intralingual translation for children who may not understand legalese, the rights here are very similar to those in the ICCPR.

${ }^{31}$ Indigenous peoples are ethnic minorities that often trace their roots to before colonization or the establishment of the nation state and that are culturally distinct from the mainstream in said nation state. Indigenous peoples are known by different names in different places, ranging from aborigines to Native Americans. Very few groups in Europe are considered indigenous peoples in this sense, and they generally live in the peripheries, such as the Sami in the Artic. Not surprisingly, only four European states have ratified this convention: Spain claims to have no indigenous people; Norway recognizes the Sami people as indigenous peoples (http://www.ilo.org/ilolex/cgilex/ratifce.pl?C169); Denmark applies the convention to the indigenous people of Greenland (http://www.ilo.org/ilolex/cgi-lex/ratifce.pl?C169); the Netherlands has also ratified the convention (http://www.ilo.org/ilolex/cgi-lex/ratifce.pl?C169). Thus, while it is an important aspect of international law for indigenous peoples (particularly in the Americas), its influence in Europe is rather limited.
} 
their state's legal system. ${ }^{32}$ Thus, if they are to stand before a tribunal to look for the protection of their rights, they may need translation.

Article 30 calls for letting indigenous peoples know what their rights are under Convention 169. According to this article, the right should be made known in a culturally sensitive way, and if needed, "by means of written translations" and mass communication in indigenous languages.

Thus, when taking Articles 12 and 30 into account, Convention 169 views translation as a means to securing rights — not specifically language rights, but a much broader set of rights regarding "labour, economic opportunities, education and health matters [and] social welfare" (Art. 30). Translation is intended to play a role in informing indigenous peoples regarding their rights but also in granting access to those rights. Consequently, translation is viewed as a means to obtaining greater rights in society without forsaking any cultural distinctiveness, including language. This is a much broader approach than that found in the ICCPR.

\subsection{International Convention on the Protection of the Rights of all Migrant Workers} and Members of their Families

The International Convention on the Protection of the Rights of all Migrant Workers and Members of their Families (ICRMW) is a United Nations treaty aimed at protecting the human rights of migrants. ${ }^{33}$ The linguistic protections in the ICRMW may seem redundant, especially in light of other treaties. However, they exist because they are intended to put migrant workers and their families on equal footing with citizens on several grounds, including the administration of justice.

Specifically, article 16 calls for the reasons behind a migrant's arrest to be communicated "in a language they [the workers] understand". That article also indicates an interpreter should be present during the subsequent, preliminary court proceedings "if they [the workers] cannot understand or speak the language used" by the tribunal. In the case of further criminal proceedings, migrant workers are guaranteed "the free assistance of an interpreter if they cannot understand or speak the language used in court" under Article 18. Finally, if a decision is made to remove the migrant from the receiving country, that decision

\footnotetext{
${ }^{32}$ International Labour Office. ILO Convention on Indigenous and Tribal Peoples, 1989 (No. 169): A Manual, (Geneva, 2003) p. 28.

${ }^{33}$ The ICRMW is in force as an instrument of international law, yet it has been ratified primarily by migrantsending countries. Migrant-receiving nations in North America, Western Europe, and the Persian Gulf have not ratified it. This dichotomy means that the treaty is really not in force in Europe, even though some of its linguistic protections can be found in European law nonetheless.
} 
must be communicated "in a language they [the workers] understand", according to Article 22. The decision to remove a migrant worker from the host nation-state is not necessarily a determination in a criminal proceeding, so this right to notice of removal (which may imply translation) may go beyond the ICCPR.

As can be seen from the brief look at the preceding instruments, general international law imposes on states very few obligations to translate. Thus, many states throughout the world can conclude their domestic translation policies are in compliance with international law if they offer translation: 1) to prisoners of war and occupied civilian populations, under specific circumstances mostly related to penal or disciplinary issues; 2) to nationals and nonnationals, during criminal proceedings (from the time when charges are presented to the sentencing), free of charge; 3 ) to indigenous peoples, during all legal proceedings in order to help them safeguard a broad set of rights; 4) to migrant workers, during criminal proceedings and removal notification. These are rather specific instances. Except for the broader rights to be secured for indigenous peoples, these obligations to translate are mostly grounded on notions of fairness in judicial proceedings and not as a means to integrate linguistic minorities.

\section{Translation as mandated by European international law}

\subsection{A "common European umbrella"}

Of course, European states are bound by general international law. And they also have to comply with an ever-growing body of law that is specific to Europe, most notably through the Council of Europe (CoE) and the European Union (EU). Because of its efforts to create a common European policy on certain non-economic areas, the CoE has championed important instruments for the protection of minorities, including linguistic minorities. This work takes place alongside that of the EU. The EU's nature is such that the economic life of the EU's member states is deeply affected by EU policies. As the EU has grown in size and scope, it has taken on social issues as well. Thus, EU law often deals with socio-economic inclusion. ${ }^{34}$ And then there is the Organization for Security and Co-operation in Europe (OSCE), which does not create binding law but has issued a number of thematic Recommendations that

\footnotetext{
${ }^{34}$ U. Schmidt, 'Language Loss and the Ethnic Identity of Minorities', ECMI Brief 16, (European Centre for Minority Issues, Flensburg, 2008), p. 6.
} 
provide guidance on how to implement international law. ${ }^{35}$ The Recommendations, while not binding themselves, are considered persuasive interpretations for member states. ${ }^{36}$ Taken together, the CoE, the EU, and the OSCE provide 'a common European umbrella with a set of values $[\ldots]$ that work towards protecting [the] identity of ethnic groups and their cultures. ${ }^{37}$

This 'common European umbrella' covers issues relating to language, including translation. Thus, in order to understand what is mandated by European international law, we need to look at legal instruments advanced by the CoE and the EU, always in the light of any relevant judicial decisions. The OSCE's understanding of these obligations can shed further light on the role of translation in Europe when it comes to linguistic minorities. Consequently, we will explore international law that is specific to Europe in the following order: $\mathrm{CoE}$ treaties, ${ }^{38} \mathrm{EU}$ regulations and directives, and OSCE recommendations.

\subsection{Convention for the Protection of Human Rights and Fundamental Freedoms}

The Convention for the Protection of Human Rights and Fundamental Freedoms (ECHR) is a $\mathrm{CoE}$ treaty that seeks to protect the human rights of individuals in Europe. Any individual who feels his or her rights under the convention have been violated in one of the CoE's member states can look for a remedy before the European Court of Human Rights (ECtHR). The ECtHR, by adjudicating the matters before it, helps define and evolve the ECHR.

Article 5 of the ECHR guarantees freedom from arbitrary arrest and detention. ${ }^{39}$ In that context, Article 5 calls for an individual who has been arrested to "be informed promptly, in a language which he understands" of the reason for the arrest or any charges against him or her. This implies translation if the person does not speak the language of the arresting authority. While the language of Article 5 seems to imply this right applies only for arrests of suspected criminals, the ECtHR in Van der Leer v. The Netherlands extended the right to be informed of reasons for arrest beyond the criminal law realm into other types of detention, including that of the mentally ill. Čonka v. Belgium's finding is consistent in that individuals arrested with the aim of removal from the state also have this right.

\footnotetext{
${ }^{35}$ High Commissioner on National Minorities, 'Report on the Linguistic Rights of Persons Belonging to National Minorities in the OSCE Area' (Organization for Security and Co-operation in Europe, The Hague, 1999), p. 7. < http://www.osce.org/hcnm/42060?download=true >, visited on 26 September 2012.

${ }^{36}$ Ibid.

${ }^{37}$ Schmidt, supra note 34.

${ }^{38}$ When looking at European legislation, the conventions pushed by the CoE are the obvious starting point. The $\mathrm{CoE}$ has been more 'energetic in framing legislation for minority protection' (including linguistic minorities) than the EU, or the OSCE of course. Schmidt, supra note 34, p. 7.

${ }^{39}$ R. Dunbar, 'Minority Language Rights in International Law', 50:1 The International and Comparative Law Quarterly (2001) p. 104.
} 
Article 6 of the ECHR guarantees the right to a fair trial. ${ }^{40}$ Article 6 states that when there is a criminal charge, the accused has the right "to be informed promptly, in a language which he understands and in detail, of the nature and cause of the accusation against him" and "to have the free ${ }^{41}$ assistance of an interpreter if he cannot understand or speak the language used in court". This right should not be read too broadly. Here is where the case law of the ECtHR helps define the limits of the right. While in Kamasinski v. Austria, the HCtHR concluded that the right to the assistance of an interpreter includes written material, not just oral statements, the same case signals this is not an unlimited right to translation-an oral explanation of the contents of a document will suffice if the explanation allows for the effective participation of the accused. In Ucak v. the United Kingdom, the court further clarified that not all materials have to be translated, only those necessary for the accused to be able to defend him or herself. Ucak also stands for the proposition that the interpreter is not formally required to be independent (e.g., the interpreter could be related to the accused) but must nonetheless provide services that are not an obstacle to the fairness of the procedures. That is not to say that any interpreter will do. According to Coban v. Spain, what matters is that the accused understand the nature of the proceedings in a way that he or she can participate in his or her defence. So any interpreter (regardless of formal qualifications) will do if he or she can accomplish proceedings that are essentially fair. Cuscani v. the United Kingdom signals, however, that ultimately the judge must guard the fairness of the proceedings in terms of language assistance. Naturally, the judge must have a reason to think the language assistance is inadequate, and the assumption seems to be that language assistance is adequate unless otherwise indicated. Indeed, Kamasinski v. Austria signals that the parties must put the judge on notice when there are problems with the adequacy of the interpreting if the judge is to exercise some control over its quality. But even if the court is put on notice that there are problems with the interpreting, according to Panasenko v. Portugal, this duty to translate is fulfilled if the problems are not serious enough to jeopardize the fairness of the procedure. Thus, the key concern is not the accused's language rights but rather fairness. This principle was declared in Isop v. Austria, when the ECtHR found that Article 6's right to a fair trial does not imply the right of the accused to choose his or her language but simply to be able to put forth his or her case. Brozicek v. Italy's conclusion that there is no

\footnotetext{
${ }^{40}$ Ibid., p. 105.

${ }^{41}$ In Luedicke, Belkacem and Koc v. Germany, the ECtHR indicated that Article 6's guarantee of free assistance of an interpreter applies regardless of the outcome of the case.
} 
need for translation if the government can establish that the accused understands the information being given him or her therefore should come as no surprise.

As in other international instruments, translation is seen in Article 6 as an indispensable element when the accused does not speak the language of the court, because fairness demands that he or she "understand and participate effectively in the proceedings". 42 This does not mean that the accused gets to choose the language. ${ }^{43}$ It is clear from the jurisprudence that the general principle from which these rights emanate is not nondiscrimination or freedom of expression but rather procedural fairness. Thus, the ECHR cannot be read to guarantee a right to communicate with public authorities in the language of one's choice. ${ }^{44}$

In essence, like the ICCPR and similar instruments of general international law, the ECHR contains very limited language rights. ${ }^{45}$ In terms of translation, those rights are limited to 1) the assistance of an interpreter at the time of arrest in order to explain the reasons for the detention and 2) translation once trial proceedings have begun in order to permit the participation of the accused in his or her defence. The next treaty we will consider breaks away from this general tendency of imposing very narrow translation obligations on states.

\subsection{European Charter for Regional or Minority Languages}

The European Charter for Regional or Minority Languages (ECRML) is rather unique. The first of its kind, it deals solely with the question of language. ${ }^{46}$ It calls for language measures "in areas where universal instruments are very deficient". ${ }^{47}$ In so doing, the ECRML focuses on languages, not people, whether individually or collectively. ${ }^{48}$ This means that the ECRML places obligations upon the states but no "legally enforceable rights ${ }^{49}$ for the minority

\footnotetext{
${ }^{42}$ Brazta, 'Training seminar for interpreters'. Paper presented the Droits de l'Homme en Europe et interprétation juridique seminar (Strasbourg, 2010) p. 1.

${ }^{43}$ N. Nic Shuibhne, EC Law and Minority Language Policy: Culture, Citizenship and Fundamental Rights (Kluwer Law International, The Hague, 2002), p. 224.

${ }^{44}$ K. Henrard, 'The Interrelationship between Individual Human Rights, Minority Rights and the Right to SelfDetermination and Its Importance for the Adequate Protection of Linguistic Minorities', 1:1 The Global Review of Ethnopolitics (2001), p. 49.

${ }^{45}$ Ibid., 48.

${ }^{46}$ Dunbar, supra note 39, p. 90.

${ }^{47}$ X. Arzoz, 'The Nature of language rights', 6:2 Journal on Ethnopolitics and Minority Issues in Europe (2007) p. 16.

${ }^{48}$ Henrard, supra note 44, p. 56.

${ }^{49}$ Naturally, the creation of a legal framework at the national level to fulfill the obligations under the charter can conceivably result in certain rights. R. Dunbar, 'The Council of Europe's European Charter for Regional or Minority Languages', in R. Dunbar and K. Henrard (eds.), Synergies in Minority Protection: European and International Law Perspectives (Cambridge University Press, Cambridge, 2008) p. 155. Nonetheless, these would be rights under national law, not directly under the charter.
} 
language communities or for individual speakers of the protected languages". ${ }^{50}$ This does not mean the ECRML is not binding. The charter provides for a monitoring system based partially on self-reporting, but there are no judicial or quasi-judicial remedies that can be sought after by individuals, ${ }^{51}$ because, as stated above, the ECRML does not create rights as such. Because of its self-reporting mechanism, the ECRML depends to a great extent on the willingness of each state to comply.

Another feature of the ECRML worth mentioning is that it explicitly offers no protection to new minority languages (also known as immigrant languages or community languages). ${ }^{52}$ Thus, the charter "distinguishes between languages which have a territorial basis and those which are not territorial". ${ }^{53}$ According to the Explanatory Report, speakers of new minority languages face unique challenges that are not addressed by the charter, so their languages (usually non-European languages) are excluded from the ECRML (para. 11). This is rather ironic, since the ECRML is not aimed at dealing with the challenges of speakers but rather with issues pertaining to non-majority languages. The ECRML's preamble states that the protection of regional or minority languages "contributes to the maintenance and development of Europe's cultural wealth and traditions". Thus, what is clearly implied by the exclusion of new minority languages is that non-European languages have nothing to bring to the table in terms of "Europe's cultural wealth and traditions". By excluding new minority languages and protecting languages instead of people, the ECRML imposes state obligations that are derived from the desire to protect minority languages (and not necessarily to grant access to minority language speakers to other rights). ${ }^{54}$

Another striking feature is the ECRML's structure as a menu of options that states can sign on to. ${ }^{55}$ The advantage of offering such options is that the ECRML thus recognizes that

\footnotetext{
${ }^{50}$ Dunbar, supra note 39, p. 100.

${ }^{51}$ F. de Varennes, 'Language Rights as an Integral Part of Human Rights - A Legal Perspective', In M. Koenig and P. de Guchteneire (eds.), Democracy and Human Rights in Multicultural Societies (2007) p. 122.

${ }^{52}$ R. Phillipson, English-Only Europe?: Challenging Language Policy (Routledge , London/New York, 2003), p. 154.

${ }^{53}$ S. Castellà Surribas, 'The Ratification by Spain of the European Charter for Regional or Minority Languages', Mercator-Working Papers 8 (CIEMEN, Barcelona, 2002) p. 3. < http://www.ciemen.org/mercator/pdf/wp8-angdef.pdf>, visited on 26 September 2012.

${ }^{54}$ In theory, new minority languages could at some point become protected by the ECMRL. Right now, the charter only covers "languages that are "traditionally used within a given territory", but as new minority languages become traditional in a territory, they could be covered in the future. P. Blair, 'The European Charter for Regional and Minority Languages', in D. Ó Riagáin (ed.) Language and Law in Northern Ireland (Queen's University Belfast, Belfast, 2003) p. 41. Even so, there is no current inclination to protect languages such as Urdu.

${ }^{55}$ Henrard, supra note 44, p. 56.
} 
each European state has its own unique linguistic and historic landscape. ${ }^{56}$ The disadvantage is that these options in some cases are very hedged, which has permitted "states to meet the requirements in a minimalist way, often legitimated by claiming that a provision was not appropriate or that numbers did not justify a provision". 57 This possibility of a minimalist approach has been criticized as having the potential to make the charter "ineffectual in practice". 58

Part I includes some general provisions regarding definitions and practical considerations, such as information to be included in the instrument of ratification. Part II outlines the charter's general objectives and principles. This part applies to all regional or minority languages, as objectively defined in the ECRML itself, so the state does not get to pick and choose which languages will benefit from this protection. ${ }^{59}$ Part III is a menu of specific measures that can be implemented. These measures are divided into specific areas: education, judicial authorities, administrative authorities and public service, media, cultural activities and facilities, economic and social life, and exchanges across borders. ${ }^{60}$ Each state that ratifies the charter ${ }^{61}$ must specify one or several languages for protection and then choose a minimum of 35 paragraphs and subparagraphs from Part III for each such language. ${ }^{62}$ Thus, the specific obligations in Part III of the charter do not apply across the board to all autochthonous minority languages. Rather, the governments get to pick and choose which language will be afforded what protections. In the ECRML, translation becomes relevant in the articles dealing with judicial authorities (Art. 9) and administrative authorities and public service (Art. 10). We will now look at each of these two articles.

Article 9, paragraph 1 applies to situations where an individual is brought before a court whose language is not the individual's first language. Like most obligations in the charter, those found in Article 9.1 are heavily hedged - they only apply to courts in regions where there are sufficient number of speakers of the non-official language and as long as they

\footnotetext{
${ }^{56}$ S. Oeter, 'Minority Language Policy: Theory and Practice' 6:1 Journal on Ethnopolitics and Minority Issues in Europe (2007) pp. 1-2.

${ }^{57}$ Schmidt, supra note 34 , p. 7.

${ }^{58}$ Nic Shuibhne, supra note 43, pp. 228-229.

${ }^{59}$ Dunbar, supra note 49, p. 167.

${ }^{60}$ Dunbar, supra note 49, p. 168

${ }^{61}$ For a study on the United Kingdom's ratification of this charter, see Dunbar, 'The Ratification by the United Kingdom of the European Charter for Regional or Minority Languages', Working Paper 10 (CIEMEN, Barcelona, 2003), < http://www.ciemen.org/mercator/pdf/wp8-ang-def.pdf >, visited on 26 September 2012. For additional issues raised, see D. Ó Riagáin, 'Language Rights / Human Rights in Northern Ireland and the Role of the European Charter for Regional or Minority Languages’, in J. M. Kirk and D. P. Ó Baoill (eds.), Linguistic Politics: Language Policies for Northern Ireland, the Republic of Ireland, and Scotland. (Cló Ollscoil na Banríona, Belfast, 2001) p. 43-54. For a study on Spain's ratification of this charter, see Castellà Surribas, supra note 53.

${ }^{62}$ Dunbar, supra note 49, p. 168.
} 
do not "hamper the proper administration of justice" (9.1). The article's first paragraph has separate subparagraphs for each of three types of courts: criminal courts, civil courts, and administrative courts. In the case of criminal courts, the accused may choose to use his or her language, present evidence in that language, and produce "on request" relevant documentation in the accused's language. To accomplish all of this, the charter stipulates "the use of interpreters and translations involving no extra expense for the persons concerned" (9.1.a). In the case of civil and administrative courts, the litigant may choose to use his or her language (at no additional expense) and present documents and evidence in that language, "if necessary by the use of interpreters and translations" (9.1.b/9.1.c). This obligation to translate in judicial matters is much broader than that imposed by the right to translation in criminal matters only as found in the ECHR and the ICCPR. The latter is based on the principle of procedural fairness, which sees translation a practical necessity. The former is based upon the notion that individuals have the right to use their own language, if they choose to, before any court, including civil and administrative courts.

Article 9, paragraph 2 indicates that legal documents drafted in an autochthonous minority language cannot be invalidated only because they are not drafted in the state's majority language. These documents can be invoked against third parties that do not speak the language of the document, as long as "the contents of the document are made known" to that third party. There is no way to achieve this without some sort of translation, even though Article 9.2 does not mandate that the full document be translated, only that its contents be made known to relevant parties who do not understand them.

Article 9, paragraph 3 places on states the obligation "to make available in the regional or minority languages the most important national statutory texts and those relating particularly to users of these languages" unless they have already been translated. According to the Explanatory Report, this is to be achieved through "the translation of legislative texts into regional or minority languages" (para. 99).

Article 10 is hedged by applying to areas where there is a sufficient number of speakers of the minority language. The article has different subparagraphs, including one that applies to administrative authorities, one that applies to local and regional authorities, and one that applies to public services. Regarding administrative authorities, the state should allow for the use of autochthonous minority languages in communicating with the authorities, both orally and in writing, and for the dissemination of the more widely used administrative texts and forms in the autochthonous language. Regarding local and regional authorities, the state should allow for the use of the autochthonous language of the local or regional population 
both within the local or regional government and to communicate with the population.

Regarding "public services provided by the administrative authorities or other persons acting on their behalf" (10.3), the state should allow for the provision of those services in the minority language. All of the above obligations may be fulfilled, among other measures including the use of bilingual staff, through "translation or interpretation as may be required" (10.4).

For speakers of languages that benefit from the full protection of the ECRML, translation can become an important tool in facilitating their use of their language in administrative, civil, and criminal proceedings, in drafting legally valid documents against third parties, in having access to legislative and administrative texts, and in communicating with public authorities, local and regional governments, and public service providers, such as hospitals. However, we should remember that not all protections will be given to all languages, and that even in the case of languages specified for protection, the obligations are heavily hedged by considerations such as the number and concentration of speakers and the practicality of implementing specific measures. In other words, the charter usually will only benefit speakers of languages that are linked to a territory in sufficient numbers and, quite candidly, with sufficient political power. Even so, the ECRML's call for translation as a means to ensure the use of autochthonous minority languages in a wide range of activities involving the state is far broader than that found in other instruments, including those that came after this charter.

\subsection{Framework Convention for the Protection of National Minorities}

The Framework Convention for the Protection of National Minorities (FCNM) "is the first modern pan-European convention aimed specifically at the protection of persons belonging to national minorities and contains a number of articles related to linguistic rights". ${ }^{63}$ It belongs to a newer type of international treaties generally known as 'framework conventions'. While there is no one technical definition for a framework agreement, these are treaties that tackle a problem by creating a framework of principles and procedures and then delegating much of the actual regulating to future agreements. ${ }^{64}$ However, the FCNM itself provides "legally binding guidance ... [that] serves as an umbrella setting the general objectives and main principles while allowing each party sufficient room to take national particularities into

\footnotetext{
${ }^{63}$ High Commissioner on National Minorities, supra note 35, p. 6.

${ }^{64}$ N. Matz-Lück, 'Framework Conventions as a Regulatory Tool', 1:3 Goettingen Journal of International Law (2009) p. 441.
} 
account". ${ }^{65}$ Further, the FCNM is monitored mainly through self-reporting before an Advisory Committee made up of independent experts. ${ }^{66}$ This means the implementation of the FCNM depends squarely upon each nation state, and individuals have very little recourse if they feel their rights under the convention have been violated.

In terms of content, the FCNM parallels the ICCPR in many aspects. ${ }^{67}$ But it has a different scope than the ICCPR (and the ECHR) in that its obligations look specifically to the protection of minorities, including linguistic minorities. ${ }^{68}$

One aspect where the FCNM parallels the ICCPR and the ECHR is in that in Article 10, paragraph 3, it binds states to ensure that individuals (belonging to minorities) in criminal proceedings be informed of the charges against them in their own language, through the free assistance of an interpreter if necessary. ${ }^{69}$ Article 10.3 also includes the right to free assistance of an interpreter to situations where such assistance may be necessary to inform someone (from a minority) of the reasons behind his or her arrest in a language that he or she understands. The Explanatory Report candidly points out the limitations of this protection: Article 10.3 "is based on certain provisions contained in Articles 5 and 6 of the European Convention on Human Rights. It does not go beyond the safeguards contained in those articles" (para. 67).

Where the FCNM does seem to reach beyond the ICCPR and the ECHR is in Article 10, paragraph 2. This paragraph calls for "the conditions which would make it possible to use the minority language in relations between those persons and the administrative authorities". In other words, the FCNM calls upon states to allow communication with administrative authorities in minority languages, something that could necessitate translation. ${ }^{70}$ The obligation is heavily hedged, even for an international instrument: "In areas inhabited by persons belonging to national minorities traditionally or in substantial numbers, if those persons so request and where such a request corresponds to a real need, the Parties shall endeavour to ensure, as far as possible, the conditions which would make it possible ..." The result is that once again we have a limited obligation, that is linked to specific territories and sufficient number of speakers and the state's political will. In essence, this means very little in

\footnotetext{
${ }^{65}$ Ibid., p. 449.

${ }^{66}$ A. Eide, 'The Council of Europe's Framework Convention for the Protection of National Minorities', In R. Dunbar and K. Henrard (eds.), Synergies in Minority Protection: European and International Law Perspectives (Cambridge University Press, Cambridge, 2008) p. 145-146.

${ }^{67}$ High Commissioner on National Minorities, supra note 35, pp. 5-6.

${ }^{68}$ Dunbar, supra note 39, p. 103.

${ }^{69}$ High Commissioner on National Minorities, supra note 35, p. 13.

${ }^{70}$ For example, the use of translation as one of several means to fulfill this obligation was explicitly mentioned by the FCNM's Advisory Committee in an opinion on Denmark. Ulasiuk, supra note 9, p. 101.
} 
terms of persuasion for a state to adopt a policy of allowing communication with the authorities in a language other than the state's language. Despite appearances to the contrary, the FCNM really goes no further in this regard than other binding international instruments.

\subsection{Convention on Preventing and Combating Violence against Women and Domestic}

\section{Violence}

On May 11, 2011, the Council of Europe opened for signature a convention to prevent violence against women and to prevent domestic violence. This treaty, which has not yet entered into force, calls for translation in an area not mentioned in other treaties. If the convention enters into force, its provisions will become part of European international law, including articles 19 and 56.

Article 19 reads: "Parties shall take the necessary legislative or other measures to ensure that victims [of violence against women or domestic violence] receive adequate and timely information on available support services and legal measures in a language they understand." Here, translation is seen as a means to allow victims access to information regarding legal and support services. This goes beyond the use of translation as a means to ensure procedural fairness or to promote the use of specific languages in public spheres. However, according to the Explanatory Report, the obligation in Article 19 could have its limitations: it "does not oblige Parties to the Convention to offer information in any language but to concentrate on the languages most widely spoken in their country". The "languages most widely spoken" in a particular state may include new minority languages, so that on its face, the obligation is not tied to territorial languages. The Explanatory Report seems to suggest that the obligation could be connected to the frequency of a language's use. Of course, this is a matter of interpretation that will have to be played out in individual states, at least until further guidance is provided.

Article 56 echoes the ICCPR and ECHR in its concern for translation during judicial proceedings. However, the focus in this convention is not on the accused but rather on the victim. Article 56, paragraph 1, subparagraph $\mathrm{h}$, calls for "providing victims with independent and competent interpreters when victims are parties to proceedings or when they are supplying evidence". This article would turn the tables of the general fairness-in-court-forthe-accused approach and ask states to consider the rights of the victim. Translation, when needed, would be a way to secure those rights.

\subsection{EU Treaties}


From consideration of CoE treaties we now move on to EU law. We note as we do that we are moving into more and more restricted geographical areas. We began with international law from a general perspective and moved to international law in Europe, as legislated by the CoE. Now we move into EU law, which only applies to European states that are members of the EU. We are moving from the top down, from the more general legal regimes to the more specific ones. In other words, the nation states that belong to the EU are bound by general international law plus CoE treaties plus EU law, and we analyse accordingly.

As we venture into the EU, we first must point out that the treaties, the EU's highest law, do not concern themselves with the language regime or translation practices of member states, not even in the Charter of Fundamental Rights of the European Union, ${ }^{71}$ which under the Treaty of Lisbon has "the same legal value as the Treaties". (Art. 8).

However, they do deal with language issues as they pertain to fundamental community freedoms, which of course can impact translation policies. The Treaty on the Functioning of the European Union contains several fundamental freedoms, including free movement of persons (Arts. 45-48), the right of establishment (Arts. 49-54), and the freedom to provide services (Arts. 55-62), and free movement of goods (Arts. 28-37). The first three fundamental freedoms have language components but do not directly deal with translation issues. Regarding the free movement of persons, the EU has adopted a policy of official language education, ${ }^{72}$ which does not necessarily mean that EU member states should not translate. In fact, under EU law language rights extended to nationals, including nationals who belong to a linguistic minority, must be extended to speakers from other member states. ${ }^{73}$ This does impact translation more directly, as will be seen below. Regarding the right of establishment and freedom to provide services, member states may impose language competence conditions on trades and professions, but these must be non-discriminatory and proportionate to the desired ends. ${ }^{74}$ Again, translating for linguistic minorities does not come across as an important issue in this regard.

Where translation issues are more readily apparent is in the free movement of goods. This freedom implies a balancing act between facilitating trade among members states and

\footnotetext{
${ }^{71}$ While the Charter of Fundamental Rights of the EU does have general provisions regarding equality before the law, non-discrimination, and even the right to a fair trial, translation does not figure in any of them. Consequently, this Charter offers no rights in terms of translation that are not already settled in instruments such as the ICCPR or the ECHR.

${ }^{72}$ Nic Shuibhne, supra note 43, pp. 22-23.

${ }^{73}$ Ibid., p. 23.

${ }^{74}$ Ibid., p. 24. 
safeguarding consumer protection. ${ }^{75}$ In that context, EU law often touches on translation issues when it comes to the free movement of goods. This is evidenced in a number of ECJ cases (e.g., Colim and Bigg's) and directives (e.g., Directive 2000/13/EC). However, the focus of this study is on translation as a way to grant language rights to linguistic minorities. Consequently, we will exclude EU law dealing with translation issues not focused on the rights of linguistic minorities, such as such as cross-border product labelling or the book trade.

What becomes apparent from this very brief discussion of language issues in the treaties of the EU is that at the treaty level, the translation policies of the member states is not a major area of concern. This is despite the fact that the EU has a much stronger say in the policies of its member states than other international institutions. In essence, member states are more or less free to implement their own language policies, but the policies must be compatible with EU law. ${ }^{76}$ To know exactly what that EU law is, we must look at secondary EU legislation, which is subject to judicial review by the ECJ. There we find some guidelines on translation for linguistic minorities. We will begin with framework decisions, where we find scant calls for translation.

\subsection{EU Framework Decisions}

3.7.1. 2002 Framework Decision on the European arrest warrant and the surrender procedures between Member States

This Framework Decision deals with translation out of concern for the rights of the accused. The Framework Decision came about as a consequence of the free movement of persons within the Union. It grew out of the perceived need to have a uniform procedure for arresting individuals in another member state, in lieu of a patchwork of onerous extradition procedures. Thus, it is concerned with establishing a level playing field in Europe, and not necessarily a linguistically diverse playing field. As will be made clear when looking at Article 11, linguistic diversity is taken as a given and no concern is expressed for promoting it.

Article 11, which deals with the rights of the person sought for arrest, involves translation. The Article indicates that the requested person "shall have a right to be assisted [...] by an interpreter in accordance with the national law of the executing Member State". The obligation to offer translation via an interpreter is hedged so as to be fulfilled according to the laws already in existence in the state that will actually execute the arrest. The

\footnotetext{
${ }_{75}^{75}$ Ibid., pp. $25-27$.

${ }^{76}$ Ibid., p. 105.
} 
assumption seems to be that such a right is already granted at the national level. Obligations certainly exist under other instruments of international law, such as the obligation to inform the person being arrested of the charges against him or her in a language that the person can understand.

\subsection{EU Regulations}

\subsubsection{Regulation No. 1612/68 on freedom of movement for workers within the}

\section{Community}

Another binding form of EU law is to be found in regulations. Due to the Union's competences focusing mainly on economic integration, EU regulations generally do not concern themselves with translation issues, unless it has an EU institutional dimension ${ }^{77}$ or is meant to facilitate cross-border cooperation. ${ }^{78}$ There are times, however, when economic concerns and the language rights of individuals interact. Such is the case of Regulation No. 1612/68 of the Council of 15 October 1968 on freedom of movement for workers within the Community.

On its face, the Regulation itself does not seem to address issues of language and translation. However, case law from the ECJ shows that there is a relationship between the free movement of workers as legislated and translation. Specifically, Article 7, paragraph 2, reads: "He [a worker who is a national of another member state] shall enjoy the same social and tax advantages as national workers." In Ministère Public v. Mutsch, the ECJ clarified that language rights asserted before a court are a social advantage for purposes of the application of this Regulation. More specifically, "a worker who is a national of one member state and habitually resides in another member state be entitled to require that criminal proceedings against him take place in a language other than the language normally used in proceedings before the court which tries him if workers who are nationals of the host member state have that right in the same circumstances" (para. 18, italics added). In essence, this decision means that any language right given to workers who speak an autochthonous minority language should be extended to foreign workers from another EU member state that speak that same language. ${ }^{79}$ In Bickel and Franz, the ECJ expanded Mutsch by clarifying that such language rights must also be extended to citizens of other EU member states in general, even if they are

\footnotetext{
${ }^{77}$ See e.g., Council Regulation (EC) No 40/94 of 20 December 1993 on the Community trade mark.

${ }^{78}$ See e.g., Council Regulation (EC) No 4/2009 of 18 December 2008 on jurisdiction, applicable law, recognition and enforcement of decisions and cooperation in matters relating to maintenance obligations.

${ }^{79}$ De Varennes, supra note 8, p. 71.
} 
just passing by the locality. Taken together, Mutsch and Bickel and Franz stand for the proposition that language rights provided domestically to speakers of a specific language "must be extended on a non-discriminatory basis to nationals of other EC Member States". 80 For example, whatever language rights a German-speaking Italian has in South Tyrol are to be extended to a German-speaking Austrian who happens to be in South Tyrol. The principle, then, seems to be non-discrimination, not necessarily the integration of linguistic minorities.

\subsubsection{Regulation (EEC) No. 574/72 laying down the procedure for implementing} Regulation (EEC) No. 1408/71 on the application of social security schemes to employed persons, to self employed persons, to self-employed persons and to their families moving within the Community

This regulation deals at length with the specific procedures to be implemented in situations where workers move from one member state to another and claim social security benefits. Article 48 indicates that when an institution makes a decision regarding social security claims, the claimant must be made aware of the decisions "in his own language by means of a summarized statement to which the aforesaid decisions shall be appended". This requirement that a summary of the decisions be provided in the claimant's own language in some cases can only be satisfied through translation. The requirement is congruent with a larger issue that is relevant to translation, as is made clear in Farrauto vs. Bau-Berufsgenossenschaft. Even though Regulation 574/72 is no at issue in Farrauto, the court does mention that regulation as an example of the principle that legal certainty requires that courts see to it that the worker is able to understand the notifications of the decisions taken by the court. Thus, when dealing with workers from other member states, some form of translation may be necessary for court decisions outside of the criminal realm. Otherwise, a climate of legal uncertainty would follow. Note that the concern here is legal certainty, not necessarily the language rights of minorities.

\subsection{EU Directives}

3.9.1. 2001 Directive 2001/55/EC on minimum standards for giving temporary protection in the event of a mass influx of displaced persons and on measures promoting a balance of

\footnotetext{
${ }^{80}$ N. Nic Shuibhne, 'The European Union and Minority Language Rights', 3:2 International Journal on Multicultural Societies (2001) p. 72.
} 
efforts between Member States in receiving such persons and bearing the consequences thereof

This directive is one of several legislative measures adopted in the slow march toward a common EU asylum system. Instruments pertaining to asylum would expectedly include obligations to translate in the interest of fairness. Directive 2001/55/EC concerns measures and procedures to grant temporary protection to individuals who enter an EU country as part of a massive influx of displaced persons (such those displaced by the conflict in the former Yugoslavia). Individuals granted such temporary protection must be given "a document, in a language likely to be understood by them, in which the provisions relating to temporary protection and which are relevant to them are clearly set out" (Art. 9). This could imply some sort of translation effort, except that states are not required to provide the document in a language the person actually understands. Consequently, the obligation to translate in this instrument is weak in that the state is left with wide discretion as to what languages the documents should be in.

3.9.2. 2005 Directive 2005/85/EC on minimum standards on procedures in Member States for granting and withdrawing refugee status

This directive is also part of the effort to create a common EU asylum system. Under it, individuals applying for asylum status are guaranteed that they will "be informed in a language which they may reasonably be supposed to understand of the procedure to be followed and of their rights and obligations during the procedure and the possible consequences of not complying with their obligations and not cooperating with the authorities" (Art. 10(a)). When the applicant is before the competent authorities, the free assistance of an interpreter must be provided if "appropriate communication cannot be ensured without such [interpreting] services" (Art. 10(1)(b)). This interpreter must be competent, but he or she need not interpret into the applicant's preferred language if there is another language in which the applicant can communicate appropriately (Art. 13(3)(b)). States, additionally, may provide written translations of documents relevant to the application for asylum (Art. 8). Thus, the directive shows a strong concern for fairness in legal settings, a trait derived from instruments of general international law, such as the Geneva Conventions and the ICCPR.

\subsubsection{Directive 2008/115/EC on common standards and procedures in Member States} for returning illegally staying third-country nationals 
Directive 2008/115/EC is also part of the effort to create a common EU asylum system. The directive focuses on the removal of "illegal migrants" (Art. 12(3)) from non-EU countries. Among the procedural safeguards called for in the directive, decisions regarding the entry, removal, and return of the non-EU national must be issued, if requested, through "a written or oral translation" into a language he or she "understands or may reasonably be presumed to understand" (Art. 12(2)). Member states are also required to "make available generalised information sheets explaining the main elements of the standard form in at least five of those languages which are most frequently used or understood by illegal migrants entering the Member State concerned" (Art. 12(3)). The concern here is once again fairness, specifically, procedural fairness.

\subsubsection{Directive $2010 / 64 / \mathrm{EU}$ on the right to interpretation and translation in criminal} proceedings

In terms of EU directives, the issue of translation features rather prominently in Directive 2010/64/EU, which deals specifically with translation in criminal proceedings. The drafters of this Directive sought to facilitate a common implementation of translation as a tool to secure the right to a fair trial, especially as found in the ECHR and the ECtHR's interpretations of that right (Directive, Preamble, recital 15). In essence, the directive "to some extent" consolidates the findings of the ECtHR regarding this right. ${ }^{81}$ Articles 2, 3, and 4 are of particular interest.

Article 2 deals with the right to interpreting. It calls for interpreting, if needed, "during criminal proceedings before investigative and judicial authorities, including during police questioning, all court hearings and any necessary interim hearings" (para. 1). Interpreting must also be provided between the accused and his or her attorney "in direct connection with any questioning or hearing during the proceedings or with the lodging of an appeal or other procedural applications" (para. 2). Article 2 also deals with the right to challenge the decision by the court that no interpreter is needed (para. 4) or to challenge the effectiveness of an interpreter once one has been assigned, if the interpreting jeopardizes "the fairness of the proceedings" (para. 5). Paragraphs 4 and 5 do not jeopardize the ECtHR notion that the judge is the ultimate guardian of the fairness of the proceedings, including issues that may arise out of language differences. However, the paragraphs do request the implementation of

\footnotetext{
${ }^{81} \mathrm{~J}$. Brannan, 'ECHR case-law on the right to language assistance in criminal proceedings and the EU response'. Paper presented at the Droits de l'Homme en Europe et interprétation juridique seminar (2010) p. 1.< http://www.eulita.eu/sites/default/files/Brannan\%20ECHR\%20case\%20law\%20_2_.pdf $>$, visited 26 September 2012.
} 
procedures to challenge a situation where the accused feels at such a linguistic disadvantage that the right to a fair trial is jeopardized.

Article 3 deals with the right to translation of essential documents. Article 3 requires EU members to provide "written translation of all documents which are essential to ensure that they [the accused] are able to exercise their right of defence and to safeguard the fairness of the proceedings" (para. 1). Such "written translations", however, need not be in writing. An oral summary may suffice (para. 7). Authorities in the proceeding are to decide which documents are essential (para. 3) based on specific criteria (para. 2). Even in documents deemed essential, passages "which are not relevant for the purposes of enabling suspected or accused persons to have knowledge of the case against them" need not be translated (para. 4). Much like in the previous article, Article 3 deals with the right to challenge the decision by the court that no translation of a specific document or passage is needed or to challenge the effectiveness of a translation that jeopardizes "the fairness of the proceedings" (para. 5).

Articles 2 and 3 also deal with the European arrest warrant. Article 2 calls for the services of an interpreter when people subject to the execution of a European warrant "do not speak or understand the language of the proceedings" (para. 7). Article 3 calls for the warrant to be translated if the person subject to the proceedings "does not understand the language in which the European arrest warrant is drawn up, or into which it has been translated by the issuing Member State" (para. 8). This makes the obligation to translate in the context of a European warrant stronger than had been mandated by the 2002 Framework Decision on the European arrest warrant.

Article 4 states that the translation (including interpreting) is free to the accused, regardless of the proceeding's outcome.

\subsubsection{Directive $2011 / 36 /$ EU on preventing and combating trafficking in human beings and} protecting its victims

The growing concern for victims under international law is reflected in EU law through this and other directives. This directive is a legal instrument that furthers the EU's commitment to preventing human trafficking and protecting the victims of such trafficking. Victims of human trafficking are particularly vulnerable for several reasons, including the fact that they are far from home and often in a place where the language spoken by the majority is not their own. The directive addresses that point by calling for measures of support that go beyond providing translation if they are party to a trial. Article 10 calls upon member states to support the victims through measures "such as [...] translation and interpreting services where 
appropriate" (para. 5). Here, a duty to translate is imposed upon member states in order to help strengthen the victim. The goal is not necessarily to integrate the victim, but rather to allow her (victims of human trafficking are very often female) to heal by giving her access to a number of services, including counselling and information.

\subsubsection{Directive 2012/13/EU on the right to information in criminal proceedings}

The EU is concerned with fairness in trial settings and is consequently moving toward a set of minimum standards in criminal proceedings. ${ }^{82}$ Of course, there are a number of general international instruments and European instruments that establish such minimum standards (see above), but the EU seeks to provide common rules for its member states in implementing those and other standards. To that end, there are currently three directives, either proposed or adopted, aimed at creating uniform rules that will increase confidence in the reality of fair criminal trials throughout the EU. ${ }^{83}$ The first such directive, Directive 2010/64/EU, is discussed above. Directive 2012/13/EU is also part of that effort and is discussed now. It too has some relevance in terms of translation.

This directive calls for accused persons to have the right to information in criminal proceedings and in the execution of a European arrest warrant. Article 3 indicates that "suspects or accused persons" (para. 1) must be given prompt information regarding their procedural rights, including "the right to interpretation and translation" 84 (para. (1)(d)). Article 4 states that anyone who is arrested or detained must promptly receive a letter of rights, listing specific rights (para. 1). This letter of rights must be provided in a language the suspected or accused person understands (para. 5). If there is no written translation available, an oral explanation must be provided in a language the person understands, but even so, a written translation must be provided "without undue delay" (para. 4). In practice, this will mean that arresting agencies will have to obtain translations of their letters of rights, either before or after the arrest.

\footnotetext{
82 Council of the European Union. 'Procedural Rights in Criminal Proceedings', (Luxembourg, 2009) p. 1-3. < http://www.consilium.europa.eu/uedocs/cms_Data/docs/pressdata/en/jha/110740.pdf >, visited on 26 September 2012.

${ }^{83}$ European Parliament, 'A "letter of rights" to ensure fair trials across the EU', (2011) p. 1.< http://www.europarl.europa.eu/pdfs/news/expert/infopress/20111213IPR33947/20111213IPR33947_en.pdf>, visited on 26 September 2012.

${ }^{84}$ The directive includes a model letter of rights which reads, in the relevant part: "If you do not speak or understand the language spoken by the police or other competent authorities, you have the right to be assisted by an interpreter, free of charge. The interpreter may help you to talk to your lawyer and must keep the content of that communication confidential. You have the right to translation of at least the relevant passages of essential documents, including any order by a judge allowing your arrest or keeping you in custody, any charge or indictment and any judgment. You may in some circumstances be provided with an oral translation or summary."
} 
This directive and Directive 2010/64/EU are presented as part of a broader strategy "to achieve a full set of procedural rights and establish a solid common level playing field throughout the European judicial area". ${ }^{85}$ As is the case with other international instruments, the concern here is not so much a desire to integrate linguistic minorities into the institutional life of the state as it is to make sure that all citizens, regardless of what languages they speak, are afforded procedural rights.

\subsubsection{Directive 2012/29/EU establishing minimum standards on the rights, support and} protection of victims of crime

This directive, alongside the yet-to-be ratified Convention on Preventing and Combating Violence against Women and Domestic Violence and some other instruments, is evidence of a growing commitment under international law in Europe for the use of translation as a means to strengthen the position of victims of crimes, particularly violent crimes. Reflective of this concern, Directive 2012/29/EU seeks to strengthen the rights of victims in the EU by laying out a set of minimum standards for the rights, support, and protection of said victims. The directive replaces the 2001 Council Framework Decision on the standing of victims in criminal proceedings. ${ }^{86}$

Regarding translation, the directive calls for translation to be provided during the victim's questioning and in certain aspects of the pertinent judicial proceedings. The victim must be provided with free translation

\footnotetext{
${ }^{85}$ V. Reding, 'Access to Justice - A Necessity in Times of Fiscal Consolidation', (Vienna, 2012), p. 1. < http://europa.eu/rapid/pressReleasesAction.do?reference=SPEECH/12/111\&format=HTML\&aged=0\&language $=$ EN\&guiLanguage $=\mathrm{en}>$, visited on 26 September 2012.

${ }^{86}$ The 2001 Council Framework Decision on the standing of victims in criminal proceedings was the first binding instrument to deal with victims' rights (regardless of their nationality). It was a milestone that was born out of the perceived disadvantages faced by victims in states other than their own, including difficulties with the local language. M. S. Groenhuijsen and A. Pemberton, 'The EU Framework Decision for Victims of Crime: Does Hard Law Make a Difference?' 17 European Journal of Crime, Criminal Law and Criminal Justice (2009) p. 43. With regards to translation for victims, articles 4 and 5 were particularly meaningful. Article 4 called for EU member states to ensure that victims had access "as from their first contact with law enforcement agencies [...] to information of relevance for the protection of their interests," and then it went on to list some ten types of information that should have been made available. Article 4 limited the translation responsibility with the following qualifier: "as far as possible in languages commonly understood." It was unclear what the "languages commonly understood" were. Article 5, on the other hand, did call for a major translation undertaking. It read, in part: "Each Member State shall, in respect of victims having the status of witnesses or parties to the proceedings, take the necessary measures to minimise as far as possible communication difficulties as regards their understanding of, or involvement in, the relevant steps of the criminal proceedings in question, to an extent comparable with the measures of this type which it takes in respect of defendants" [italics added]. In terms of translation, member states should have provided a "comparable" level of translation to victims as compared to the accused. It was hard to gauge what a "comparable" level of translation meant in practice. At the very least, it means translation during the questioning of the victim and of all relevant documents. Ibid., p. 52
} 
"during questioning of the victim and in order to enable them to participate actively in court hearings, in accordance with the role of the victim in the relevant criminal justice system. For other aspects of criminal proceedings, the need for interpretation and translation can vary depending on specific issues, the role of the victim in the relevant criminal justice system and his or her involvement in proceedings and any specific rights they have. As such, interpretation and translation for these other cases need only be provided to the extent necessary for victims to exercise their rights." (recital 34). More specifically, Article 3 calls on member states to "take appropriate measures to assist victims to understand and to be understood from the first contact and during any further necessary interaction they have with a competent authority in the context of criminal proceedings" (para. (1)). When the victim cannot understand or speak the language of the state, translation becomes a tool to enable compliance with this article. Further, under Article 4 , victims are to be offered information regarding how to access their rights under this directive, including "how and under what conditions they are entitled to interpretation and translation" (para. (1)(e)).

Article 5 allows victims who do not speak or understand the language of the authorities to make a complaint of a criminal offence "in a language that they understand or by receiving the necessary linguistic assistance" (para. (2)) and to receive "written acknowledgement of their complaint" through free translation (para. (3)). This is true to the directive's indication that victims who do not speak the language of the authorities, in order to be fully enjoy their rights in the redress of the crime, must be provided with language assistance, which often takes the form of translation.

Article 7 in its entirety deals with the issue of translation for victims that may need it. The article indicates generally that victims who do not speak the language of the authorities must be provided with interpretation, if they request it and

"in accordance with their role in the relevant criminal justice system in criminal proceedings, free of charge, at least during any interviews or questioning of the victim during criminal proceedings before investigative and judicial authorities, including during police questioning, and interpretation for their active participation in court hearings and any necessary interim hearings." (para. 1).

They must also be provided with (written) translation of documents "essential to the exercise of their rights in criminal proceedings" if requested, including at least "decision[s] ending the criminal proceedings [...] and upon the victim's request, reasons or a brief summary of reasons for such decision" (para. 3). Additionally, "victims who are entitled to information 
about the time and place of the trial" must receive that information through translation, if needed (para. 4).

Under certain circumstances, this translation may take the form of an "oral translation or oral summary of essential documents" (para. 6). Essential documents are those that are "relevant for the purpose of enabling victims to actively participate in the criminal proceedings" (para. 5). If the victim is denied translation, the draft calls for a mechanism to challenge the decision (para. 7). There is a hedge to all this translation for victims: "Interpretation and translation [...] shall not unreasonably prolong the criminal proceedings" (para. 8).

This use of translation is intended to allow the victim to exercise his or her rights. In this regard, the right to translation becomes more than a way to assure procedural fairness for the accused in a trial setting. In expanding the role of translation in judicial proceedings, it follows in the footsteps of the Framework Decision on the standing of victims in criminal proceedings and the Directive on preventing and combating trafficking in human beings and protecting its victims.

\subsection{The OSCE's HCNM Oslo Recommendations regarding the Linguistic Rights of National}

\section{Minorities}

Having concluded our survey of binding international instruments that have a bearing on European states' obligation to translate, we now turn to the OSCE's High Commissioner on National Minorities' thematic recommendations. As stated above, even though the recommendations are not themselves binding, they are considered by some to be persuasive interpretations of international obligations vis-à-vis minorities, including linguistic minorities, for Europe. When looking at the obligation to translate, the 1998 Oslo Recommendations Regarding the Linguistic Rights of National Minorities (Oslo Recommendations) are most relevant.

The Oslo Recommendations come as the result of two expert consultations regarding the linguistic rights of national minorities. ${ }^{87}$ The Recommendations draw on general principles of law found, inter alias, in non-binding documents, such as the UN Declaration on

\footnotetext{
${ }^{87}$ A. Bloed and R. Letschert, 'The OSCE High Commissioner on National Minorities', in R. Dunbar and K. Henrard (eds.), Synergies in Minority Protection: European and International Law Perspectives (Cambridge University Press, Cambridge, 2008) p. 104.
} 
the Rights of Persons Belonging to National or Ethnic, Religious and Linguistic Minorities. ${ }^{88}$ They are also derived from international instruments that are legally binding on most OSCE participating states. ${ }^{89}$ Because such instruments are often vague and general, the Oslo Recommendations attempt "to develop these [...] elements of international law into more precise and detailed provisions which can guide language policies better than the general international standards on which they are based". 90 This means that the Oslo

Recommendations become more than an interpretation of international law regarding linguistic minorities. They "draw progressive inferences" 91 in an attempt to move forward the linguistic protection of minorities. ${ }^{92}$ In this regard, we can think of the recommendations as a view of what European law should be.

The Oslo Recommendations touch upon the right to communicate with administrative authorities in a language other than the national or official language. Recommendations 13 and 14 indicate that such a right should be granted where there are enough speakers of a minority language and these speakers express their desire for such a right. Recommendation 13 suggests that "persons belonging to this national minority shall have the right to acquire civil documents and certificates both in the official language or languages of the State and in the language of the national minority in question from regional and/or local public institutions". In turn, Recommendation 14 suggests that linguistic minorities should have the possibility of communicating with the administrative authorities and of receiving public services in their own language. The broad proposition found in these two recommendations, and also in Recommendation $15,{ }^{93}$ is that the language of the minorities may be a vehicle for communication with public authorities. ${ }^{94}$ It should be noted that translation is not mentioned

\footnotetext{
${ }^{88}$ High Commissioner for National Minorities, 'The Oslo Recommendations regarding the Linguistic Rights of National Minorities \& Explanatory Note', (Organization for Security and Co-operation in Europe, The Hague, 1998) p. 12. < http://www.osce.org/hcnm/67531?download=true >, visited on 26 September 2012.

${ }^{89}$ A. Eide 'The Oslo Recommendations Regarding the Linguistic Rights of National Minorities: An Overview'. 6 International Journal on Minority and Group Rights (1999) p. 324.

${ }^{90}$ Ibid.

${ }^{91}$ Henrard, supra note 44, p. 46.

${ }^{92}$ For example, when making a recommendation about economic life, the Explanatory Report acknowledges that there is "little reference to the rights of persons belonging to national minorities in the field of economic activity" in the relevant instruments, but nonetheless the Oslo Recommendations extrapolate a specific right derived from the oft-recognized right to use one's language in private and in public. High Commissioner for National Minorities, supra note 88, p. 24.

${ }^{93}$ Recommendation 15 reads: "In regions and localities where persons belonging to a national minority are present in significant numbers, the State shall take measures to ensure that elected members of regional and local governmental bodies can use also the language of the national minority during activities relating to these bodies."

${ }^{94}$ A. H. E. Morawa, 'Minority Languages and Public Administration. A Comment on Issues Raised in Diergaardt et al. v. Namibia', Working Paper 16 (2002) p. 9. <

http://www.ecmi.de/uploads/tx_lfpubdb/working_paper_16.pdf >, visited 26 September 2012.
} 
as a way to carry out Recommendations 13 and 14. Yet if the state's primary language is one other than the language of the minority, translation becomes one of several tools ${ }^{95}$ to achieving the stated aim.

Recommendations 17 and 18 focus on language rights when dealing with judicial authorities. Article 17 echoes the very obvious international obligation to offer all persons the free assistance of an interpreter when faced with arrest and detention, as well as "before trial, during trial and on appeal" in order to mount a defence. Article 17 makes it clear that this is not necessarily a right to interpreting into the accused person's own language but rather a right to interpreting into a language the accused understands. However, Article 18 signals that if there are enough speakers in a certain locality and these speakers express such a desire, accused persons "have the right to express themselves in their own language in judicial proceedings, if necessary with the free assistance of an interpreter and/or translator".

Recommendation 20 turns to the penal phase. It suggests that the staff working at penal institutions should speak a language that the majority of the prisoners understand. If needed, "the services of an interpreter shall be used". This recommendation views translation as a tool for effective communication between individuals deprived of liberty and their captors. Much like in the Geneva Conventions, a concern for the principle of fairness is evidenced in this Recommendation.

At this point we have concluded our survey of binding instruments (and their authoritative interpretations) regarding the obligation to translate under international law. Having an idea of what these international obligations are, we can now draw some conclusions regarding when European states are required and are not required to translate under international law.

\section{Conclusion}

We return to our initial question: "What translation must take place in domestic policies under existing international law?" Broadly speaking, European states are required to translate in four types of situations: 1) in times of war; 2) in judicial matters; 3) for communications with the authorities; and 4) during the provision of public services. Enough has been said about the duty to translate during times of war, ${ }^{96}$ so we will look at the other three categories.

\footnotetext{
${ }^{95}$ Other tools may include the hiring and training of bilingual staff. But even here, said staff would presumably engage in translation activities from time to time.

${ }^{96}$ See section 2.2.
} 
The most explicit obligations to translate under international law are to be found in judicial matters, at least compared to other situations. This is particularly true in criminal proceedings, from the time of the initial arrest all the way to the issuing of the sentence. International law is quite influential in shaping this aspect of national translation policy, particularly in Europe. ${ }^{97}$ Thus, the right of the accused to translation is found in most major human rights instruments, such as the ICCPR, Convention 169, the ICPRMW, the FCNM, and even the EU's Directive 2010/64/EU. This right is also extended to victims in instruments such as the directive establishing minimum standards on the rights, support and protection of victims of crime. It should be noted there is no right to translation into an individual's native language per se, but only into a language the person can understand. Most international instruments shy away from extending these protections to other type of judicial proceedings, including civil and administrative proceedings. However little this international obligation extends beyond the criminal realm is the result of duties imposed by courts. As we analyse these obligations, it seems apparent that the duty to translate in criminal proceedings is a procedural safeguard aimed at securing the right to a fair trial, which includes the right to mounting a defence. ${ }^{98}$ This same concern for procedural fairness is reflected in the obligations to translate in proceedings that affect refugees, asylum seekers, or illegal migrants.

Procedural fairness in judicial settings is a desirable goal. When there are language barriers, it helps foster equality by creating access to the judiciary for people who would otherwise not have it. This is, of course, a form of integration of linguistic minorities, at least of those who cannot speak the language of the court sufficiently well. It is a form of integration because it allows greater contact and interaction between state institutions and individuals who do not speak the language of the state. However, it is a modest form of integration, as it only applies to specific types of procedures (usually criminal) in the rather narrow context of the courts. The broader ways in which linguistic minorities could interact with the state via translation are often overlooked in international law.

There are two major exceptions to the general observations in the previous paragraphs. One is the rather exceptional ECRML. This charter calls for translation during criminal proceedings into a limited amount of autochthonous minority languages, which languages are specified by each ratifying state. It also provides for translation in non-criminal proceedings.

\footnotetext{
${ }^{97}$ See E. Hertog (ed.), Aequalitas. Equal Access to Justice across Language and Culture in the EU Grotius project 2001/GRP/015, (Lessius, Antwerp, 2003) p. 8-9. < http://www.agisproject.com/Documents/Aequalitas.pdf>, visited 26 September 2012.

${ }^{98}$ See V. Cardi, 'Regional or Minority Language Use before Judicial Authorities: Provisions and Facts' 6:2 Journal on Ethnopolitics and Minority Issues in Europe (2007) p. 4-5.
} 
The charter is unusual in that it is not aimed at securing rights for individuals but rather at protecting a certain category of languages, namely the so-called 'regional minority languages'. The other instrument that extends the right to translation in judicial matters beyond the criminal realm is Convention 169. Unlike the ECRML, the drafters of this convention were indeed concerned with the rights of individuals, in this case those of indigenous peoples. By extending the right to translation into non-criminal proceedings, Convention 169 foresees a role for translation as a means to secure a broader set of rights. When the rights of indigenous peoples are threatened by the majority, those peoples can rely on translation for their day in court. In this light, translation becomes a tool for empowerment against assimilation into the majority.

It is also appropriate to note that increasingly we find an awareness under international law of the role that translation may play for victims of crimes ${ }^{99}$, not just during criminal proceedings but also in other situations that are a result of their victimization. For victims, translation becomes a tool for fairness in judicial proceedings and a way to secure other rights pertinent to the proceedings. It also becomes a tool for access to services that may be necessary to make the victim whole.

Regarding translation as a means to communicate with the authorities, only the ECRML calls for those communications with the authorities to take place in a minority language. The FCNM apparently does the same thing, but the obligation is heavily hedged. The right to communicate with the authorities is rather weak in international law. ${ }^{100}$ Even so, experts such as those that drafted the OSLO recommendation feel this is a direction states should move toward, albeit with important limitations (such as number of speakers and expressed desire), based on principles such as non-discrimination. Despite some consensus among European nation states that members of minority groups should enjoy some rights to communicate with the public authorities in their own language, the application of that consensus is vague and weak at best. ${ }^{101}$ Translation would be one of several ways to apply that weak consensus. ${ }^{102}$ However, what limited translation does currently take place in public

\footnotetext{
${ }^{99}$ The increasing role of translation in victim's rights under international law can be seen by comparing Council Framework Decision of 19 July 2002 on combating trafficking in human beings with Directive 2011/36/EU of the European Parliament and of the Council of 5 April 2011 on preventing and combating trafficking in human beings and protecting its victims. The latter updated and replaced the former. In the framework decision no mention is made of translation as a tool to help victims. In the directive's Article 10 translation is specifically mentioned as a way to assist victims.

${ }^{100}$ Ulasiuk, supra note 9, p. 96.

${ }^{101}$ Morawa, supra note 94, pp. 15-16.

${ }^{102}$ Ulasiuk, supra note 9, p. 113.
} 
institutions, especially when it comes to new minority languages, is not always mandated by international instruments. ${ }^{103}$

Regarding translation in many types of public services, there is very little to make states feel bound to engage in such a work. Both Convention 169 and Directive 2012/29/EU call for translating certain documents for the benefit of different groups. But these obligations are rather narrow, and the more common services, such as healthcare, are largely unaffected by any obligation to translate. Only the ECRML and the FCNM call for language policies in the public service sector to include the use of languages other than the central state's language.

This does not mean that states are not employing translation as a tool in their public service provision. Out of necessity, they must to a certain extent. ${ }^{104}$ However, they are under no explicit international law obligation to do so. Take, for example, Directive 2011/24/EU on the application of patients' rights in cross-border healthcare. While it is expected that crossborder healthcare issues include translation, Directive 2011/24/EU largely does not concern itself with that. Article 4, which deals with the responsibilities of member states for treatment, reads in paragraph 5: "This Directive shall not affect laws and regulations in Member States on the use of languages. Member States may choose to deliver information in other languages than those which are official languages in the Member State concerned.” This blunt statement in Directive 2011/24/EU simply reinforces the notion that issues of language in healthcare are not contemplated in international law.

The fact that states are under no specific international obligation to provide translation in healthcare settings is particularly problematic. It is problematic because language barriers can have a real impact on healthcare provision. There is evidence to indicate that language barriers can limit access to healthcare. ${ }^{105}$ This linguistic challenge should not be underestimated. Spolsky points to mistreatment, misdiagnosis, misprescriptions, and other challenges as examples of the scope of the problem. ${ }^{106}$ Doctors and nurses are like lawyers,

\footnotetext{
${ }^{103}$ R. Dunbar, 'Minority Language Rights Regimes: An Analytical Framework, Scotland, and Emerging European Norms', in J. M. Kirk and D. P. Ó Baoill (eds.), Linguistic Politics: Language Policies for Northern Ireland, the Republic of Ireland, and Scotland. (Cló Ollscoil na Banríona, Belfast, 2001) pp. 231-254.

${ }^{104}$ For example, in the United States, Executive Order 13166 sought to improve access to services for persons who did not speak English by requesting federal agencies and agencies funded by the federal government to find ways to provide services to people who have limited English proficiencies. B. Spolsky, Language Management, (Cambridge University Press, Cambridge, 2009) p. 121. No doubt, translation is one way to achieve the aims of this executive order.

${ }^{105}$ S. Bowen, 'Language Barriers in Access to Health Care', (Health Canada, 2001) p. 95. < http://www.hcsc.gc.ca/hcs-sss/alt_formats/hpb-dgps/pdf/pubs/2001-lang-acces/2001-lang-acces-eng.pdf>, visited on 26 September 2012.

${ }^{106}$ Spolsky, supra note 104, p. 126.
} 
judges, and police officers in that they tend to be majority language speakers while their patients are often in a high proportion speakers of minority languages. ${ }^{107}$ Even so, doctors frequently expect friends or family (including children) of the patient to provide translation when it is needed. ${ }^{108}$ The difficulties can have lethal consequences: it is estimated that in the United States, 98,000 deaths could be avoided each year if labels on prescription medication were translated from English. ${ }^{109}$

It is also problematic because states have generally not been keen to put the issue of translation in healthcare on their legislative agendas. Of course, some states pressure healthcare providers into using translation to address the issues mentioned in the previous paragraph. For example, in the UK there is extensive non-discrimination legislation that healthcare providers often see as triggering the need to translate. But not all states have legislated in a way that healthcare providers feel the need to translate. At that point, the level of translation provision becomes a matter of policy for each institution. Some healthcare providers deal with the problems of multilingualism in structured, systematic ways. For example, Intermountain Healthcare, a regional non-profit hospital and medical services provider in the USA, employs 14 full-time interpreters, a host of contract interpreters, and multilingual staff to provide medical services in over eighty languages. ${ }^{110}$ Even so, in many places, provision of language support measures is not nearly as responsible. For example, in hospitals in countries like Germany, Hungary, Ireland, Italy and Spain, it has been reported that staff interpreters are not always available, and in some cases translation is improvised by bringing in bilingual cleaning staff or even security personnel. ${ }^{111}$ Again, part of the reason that no translation policies are adopted by these healthcare providers is the lack of national legislation to compel the use of translation in healthcare settings. ${ }^{112}$ And international law does next to nothing to pressure governments into taking action. ${ }^{113}$

\footnotetext{
${ }^{107}$ Ibid.,p. 115.

${ }^{108}$ Committee of Experts on Health Services in a Multicultural Society. 'Adapting Health Care Services to Cultural Diversity in Multicultural Europe: Explanatory Memorandum’ (2006), p. 15.

$<$ https://www.google.be/url?sa=t\&rct=j\&q=\&esrc=s\&source=web\&cd=1\&ved=0CCwQFjAA\&url=https\%3A $\%$ 2F\%2Fwcd.coe.int\%2Fcom.instranet.InstraServlet\%3Fcommand\%3Dcom.instranet.CmdBlobGet\%26InstranetI mage\%3D504514\%26SecMode\%3D1\%26DocId\%3D1037724\%26Usage\%3D2\&ei=ctpiUOLmAcOl0QWF2IC YCw\&usg=AFQjCNFMEzZHrMQYzuDJ5xLODmhusk5rfg\&cad=rja>, visited on 26 September 2012.

${ }^{109}$ Spolsky, supra note 104, p. 126.

${ }^{110}$ W. Leonard, 'Diagnoses offered in 80+ tongues', Deseret News, 20 June 2011, pp. A1, A5.

${ }^{111}$ European Union Agency for Fundamental Rights, 'Migrants in an irregular situation: access to healthcare in 10 European Union Member States' (Publications Office of the European Union, Luxembourg, 2011), p. 49. < http://fra.europa.eu/fraWebsite/attachments/FRA-2011-fundamental-rights-for-irregular-migrantshealthcare_EN.pdf >, visited on 26 September 2012.

${ }^{112}$ Bowen, supra note 105 .

${ }^{113}$ This is also true when it comes to speakers of autochthonous minority languages who also speak the majority language, but in a very different way. In their case, states that apply Article 13(2)(c) to at least one of their
} 
Issues of translation in public services, especially in healthcare, are often ignored in international law, even in the face of a vague consensus that some sort of translation may be appropriate in related matters, such as when communicating with authorities. This is the case because the only place where translation is very strongly mandated and nourished by international law is the judicial realm, especially in criminal proceedings. Such a safeguard during criminal proceedings is desirable, but perhaps the time has come for international law to take up the issue of translation in non-judicial settings more forcefully. After all, one is more likely to walk into a hospital than a courthouse...

This is an Author's Accepted Manuscript of an article published in the International Journal on Minority and Group Rights (C) Brill, available online at: http://booksandjournals.brillonline.com/content/10.1163/15718115-02003004.

regional or minority languages ought to "ensure that social care facilities such as hospitals [...] offer the possibility of receiving and treating in their own language persons using a regional or minority language". According to the Committee of Experts, this provision is not to be fulfilled via translation, because translation is understood to be an insufficient means of communication between speakers of autochthonous minority languages and healthcare staff, i.e., communication should take place in the autochthonous minority language sans intermediaries. I. Urrutia Libarona, 'Article 13. Economic and Social Life', In A. Nogueira López, E. J. Ruiz Vieytez and I. Urrutia Libarona (eds.), Shaping Language Rights: Commentary on the European Charter for Regional or Minority Languages in Light of the Committee of Experts' Evaluation (Council of Europe Publishing, Strasbourg, 2012) p. 474. 